\title{
Title:
}

\section{Risks Associated with Animal-Assisted Intervention Programs: A Literature Review}

\section{Short Title: AAI Risk Literature Review}

Authors:

Kathryn R. Dalton ${ }^{1}$, Kaitlin B. Waite ${ }^{1}$, Kathy Ruble ${ }^{2}$, Karen C. Carroll ${ }^{3}$, Alexandra DeLone ${ }^{2}$, Pam Frankenfield $^{2}$, James A. Serpell ${ }^{4}$, Roland J. Thorpe, Jr. ${ }^{5}$, Daniel O. Morris ${ }^{4}$, Jacqueline Agnew ${ }^{1}$, Ronald C. Rubenstein ${ }^{6,7}$, and Meghan F. Davis ${ }^{1,8}$

1. Johns Hopkins University Bloomberg School of Public Health, Department of Environmental Health and Engineering, Baltimore Maryland

2. Johns Hopkins University School of Medicine, Department of Pediatric Oncology, Baltimore Maryland

3. Johns Hopkins University School of Medicine, Department of Pathology, Division of Medical Microbiology, Baltimore Maryland

4. University of Pennsylvania School of Veterinary Medicine, Department of Clinical Sciences \& Advanced Medicine, Philadelphia Pennsylvania

5. Johns Hopkins University Bloomberg School of Public Health, Department of Health, Behavior and Society, Baltimore Maryland

6. The Children's Hospital of Philadelphia, Cystic Fibrosis Center, Philadelphia Pennsylvania

7. The University of Pennsylvania Perelman School of Medicine, Department of Pediatrics, Philadelphia Pennsylvania

8. Johns Hopkins Medicine, Department of Molecular and Comparative Pathobiology, Baltimore Maryland

Corresponding Author:

Kathryn Dalton

KDalton4@jhu.edu

$615 \mathrm{~N}$ Wolfe St

JHSPH EHE W7034G

Baltimore MD 21205 


\section{Abstract}

The benefits of animal-assisted interventions (AAI), to utilize companion animals as an adjunctive treatment modality, is well-established and a burgeoning research field. However, few studies have evaluated the potential hazards of these programs, such as the potential for therapy animals to transfer hospital-associated pathogens between individuals and the hospital environment. Here we review the current literature on the possible risks of hospital-based AAI programs, including zoonotic pathogen transmission. We identified twenty-nine articles encompassing reviews of infection control guidelines and epidemiological studies on zoonotic pathogen prevalence in AAI. We observed substantial heterogeneity in infection control practices among hospital AAI programs. Few data confirmed pathogen transmission between therapy animals and patients. Given AAl's known benefits, we recommend that future research utilize a One Health framework to evaluate microbial dynamics among therapy animals, patients, and hospital environments. This framework may best promote safe practices to ensure the sustainability of these valuable AAI programs.

Keywords: Animal-assisted interventions; zoonotic infections; hospital-associated infections; hospital infection control

\section{Highlights:}

- Despite the many benefits of animal-assisted interventions (AAI) for patients, there is a risk of therapy animals becoming vectors of hospital pathogens.

- There is an absence of literature on transmission of hospital pathogens between patients and therapy animals during an AAI session.

- More research is needed to improve the safety and utilization of this important adjunctive therapy. 
medRxiv preprint doi: https://doi.org/10.1101/2020.02.19.20025130; this version posted February 23, 2020. The copyright holder for this preprint (which was not certified by peer review) is the author/funder, who has granted medRxiv a license to display the preprint in perpetuity.

All rights reserved. No reuse allowed without permission.

\section{Introduction}

The emotional benefits of human-companion animal relationships are well established in the scientific literature (Serpell, 1996). This concept has extended into the development of animalassisted interventions (AAI), in which visiting animals participate as an adjunctive treatment in holistic patient care. AAI programs are increasingly popular in various healthcare settings and utilized for patients with widely diverse conditions, including mental health disorders and cancer. Research into the benefits of AAl continues to expand, with the many advantages of these programs supported by numerous epidemiological studies and meta-analyses that standardize and integrate these findings. These data support the hypothesis that AAI programs reduce patient stress, pain, and anxiety levels when incorporated into patients' treatment plans (Bert et al., 2016; Kamioka et al., 2014; Lundqvist et al., 2017; Maujean et al., 2015; Serpell et al., 2017).

However, infection control is a persistent problem in healthcare settings, both in routine care and in the use of complementary therapies. Similar to known fomites in hospitals, such as door handles and clinicians' stethoscopes (Haun et al., 2016), therapy animals may unwittingly serve as mechanical vectors of hospital-associated pathogens, and contribute to the transmission of these pathogens between patients, or otherwise within the hospital environment. Patients can experience different levels of animal exposure from petting and licking, which can result in contamination of both the patient and the animal, thereby providing the opportunity for the spread of microorganisms (Lefebvre \& Weese, 2009). Therapy animals also have the potential to introduce zoonotic pathogens directly into the hospital environment, for example, via the consumption of contaminated foods (Lefebvre et al., 2008b). Contamination by a pathogen could potentially lead to pathogen replication and stable colonization; this is concerning not only for the possible risk of progression to infection, but also for the risk that the therapy animal may serve as a reservoir and spread these pathogens to the home and larger community (Enoch et 
al., 2005). Such perceptions of potential infection control challenges and resulting harm could limit the use of AAI programs and detract from their employment as a valid and valuable adjunctive therapy for patients.

This review examines the current literature that focuses on potential hazards associated with hospital-based AAI therapy programs. We assessed both the breadth and quality of existing literature regarding infection control in AAI programs; these are discussed in the context of known and hypothetical pathways of microbial transmission. By identifying knowledge gaps, we provide focus for future research efforts and intervention strategies that will ultimately promote the sustainability of these AAI programs. 


\section{Methods}

\subsection{Search Strategy}

This review utilized a more flexible search strategy in order to optimize capture of the peerreviewed literature related to the risk of animal-assisted therapy. Multiple search approaches and terminology were employed to capture existing evidence relating to animal-assisted interventions for patients as a whole. Several unique terms can apply to AAI, such as animalassisted therapy, animal-assisted activities, or pet therapy, therefore the search strategy was intentionally broad.

The literature search on risks of animal use in hospitals was carried out using the following databases: PubMed, Scopus, Embase, Web of Science, CINAHL, and Cochrane Trials. The search was completed concurrently and independently by two of the authors (KRD, KBW), and the search strategy was framed using PICO (Population, Intervention/Exposure, Comparators, Outcomes) terms (Miller \& Forrest, 2001). The Population was identified as healthcare-based AAl programs using any therapy animals, not just canines. The Intervention/Exposure and Comparators were kept flexible and were dependent on study design. The Outcomes were any potential hazards associated with AAI, particularly infectious disease, microbial, or biological risks. Study designs accepted for review remained flexible and included original epidemiological research, literature reviews, commentaries, and case-reports.

\subsection{Search Terms}

In collaboration with a librarian, we performed a systematic search using the terms listed below on the respective databases; search terms were adjusted according to individual database terminologies, and searches were restricted to title/abstract. We used the following search strategy for the PubMed database: animal assist* OR pet assist ${ }^{\star}$ OR dog assist* OR pet therap* OR dog therap* OR animal therap* OR "animal facilitated" OR "pet facilitated" OR "therapeutic 
animal" OR "therapeutic animals" OR "therapeutic canine" OR "therapeutic canines" OR "therapeutic dog" OR "therapeutic dogs" OR [Animal Assisted Intervention MeSH Term]. Similar keywords were used to conduct searches within the other selected databases.

\subsection{Inclusion and Exclusion Criteria}

The articles identified from this broad search were then individually and independently screened by two of the authors (KRD, KBW), based on the title and abstract, for inclusion based on the following criteria:

- Did the article explain possible complications or hazards to either therapy animals or patients that can occur during a hospital AAI therapy session?

- Did the article describe an epidemiological study demonstrating the risk of animals within health care environments?

- Did the article provide novel commentary on current guidelines, or recommend new guidelines, for reducing associated risks of animals within healthcare environments?

Articles that did not address any of the above criteria, or written in a language other than English, were excluded. Eligible studies underwent full-text review to further confirm eligibility (by KRD \& KBW, arbiter MFD). After full-text review, references were examined to look for additional relevant articles that fit the inclusion criteria. We then extracted data from the selected studies on the research aims, study design, study population, exposure characteristics, type of intervention (if any), reported outcomes, and results. These data were then synthesized by study goals and outcomes. 


\section{Results}

\subsection{Search Outcomes}

The initial database search returned a total of 5480 unique results (maximum number of returned articles from Embase), as shown in the flow diagram in Figure 1. After title and abstract screening of these articles, 110 were deemed potentially relevant based on the inclusion criteria. The remaining 5370 articles did not meet our prespecified criteria for inclusion, most commonly because the excluded articles evaluated the benefits of AAI programs on patient care. Upon full-text review of the 110 potentially relevant articles, 86 articles were removed because they did not satisfy the inclusion criteria. An additional five articles were added after reviewing the reference lists of the remaining included papers. These five articles were not found in the initial database search because they were either 1) not located in the selected databases or 2) had improperly labeled keywords. A summary of the final 29 total articles reviewed can be found in Tables 1 and 2. Thirteen articles were reviews or commentaries of current AAI guidelines that refer to therapy animals in healthcare settings, and sixteen articles were data-acquiring or epidemiological studies (6 cohort studies, 5 crosssectional studies, 4 case reports, and 1 ecological study). Most studies focused on therapy animals broadly or therapy dogs exclusively, but three studies included cats (Boyle et al., 2019; Coughlan et al., 2010; Sillery et al., 2004).

\subsection{Commentaries and Review Articles}

Of the 13 commentaries and reviews, there were a total of 7 commentaries and letters to the editors and 6 systematic or unstructured literature review articles. Four of the six reviews (Brodie et al., 2002; Cimolai, 2015; Guay, 2001; Sehulster \& Chinn, 2003) and four of the seven commentaries (Disalvo et al., 2006; Khan \& Farrag, 2000; Lefebvre et al., 2008a; Murthy et al., 2015) focused on risks associated with infection control. The remaining articles primarily 
medRxiv preprint doi: https://doi.org/10.1101/2020.02.19.20025130; this version posted February 23, 2020. The copyright holder for this preprint (which was not certified by peer review) is the author/funder, who has granted medRxiv a license to display the preprint in perpetuity.

All rights reserved. No reuse allowed without permission.

discussed AAI benefits, with only a brief mention of hazard reduction. Zoonotic infection and pathogen transmission were the primary hazards discussed, although some papers mentioned injury risk. One article, endorsed by the Society for Healthcare Epidemiology of America (SHEA), is the current source for the medical community on general guidance for animals in healthcare settings, both summarizing existing policies in hospitals and recommending practical directives to minimize risk (Murthy et al., 2015). In this article, the authors also acknowledge that this field remains insufficiently studied (Murthy et al., 2015). There was a consensus among the reviews and commentaries that with proper hospital infection control protocols in place, the risks associated with animal-assisted activities are minimized. All articles recommended using standardized regulations across healthcare facilities for infection control practices for patients and therapy animals. Three of the articles strongly recommended utilizing expert consultation in various animal and human health care fields, as well as environmental microbiology, to evaluate all possible routes of pathogen transmission (Chalmers \& Dell, 2016; Disalvo et al., 2006; Waltner-Toews, 1993).

\subsection{Epidemiological Studies}

The three studies that surveyed hospital infection control policies demonstrated dissimilarities across hospitals. Among the combined 186 facilities surveyed, infection control policies regarding therapy animals varied, with 13\% (Linder et al., 2017; Murthy et al., 2015) to 90\% (Waltner-Toews, 1993) of healthcare facilities having no existing standardized policies. Only $28 \%$ of facilities required documentation that the animal was healthy, and only $29 \%$ allowed solely registered therapy animals (Linder et al., 2017). In addition to clinical practice policy discrepancies, animal handler knowledge of infectious disease concerns and adherence to infection control policies varied across and within institutions. Lefebvre et al. found that $20 \%$ of 90 surveyed handlers did not practice any infection control and $40 \%$ of these handlers were unable to name one zoonotic disease or pathogen that may be transmitted by means of their 
dog, while Boyle et. al. found that $70 \%$ of their 40 handler respondents expressed no concerns regarding infectious disease transmission in AAl settings (Boyle et al., 2019; Lefebvre et al., 2006b). These institutional and individual discrepancies in AAl programs drive diversity in infection control practices both across and within healthcare facilities.

Three studies reviewed electronic medical records to compare a change in the rate of diagnosed infections from AAl exposure. One study evaluated hospital-wide infection rates one year after the introduction of an AAI program in a pediatric hospital and, comparing these rates to the previous year, found no changes in overall infections or detected pathogens reported by the hospital's infection control committee (Caprilli \& Messeri, 2006). Another prospective cohort study followed 11 adult cardiac patients after receiving multiple AAI therapy sessions (average of 13 visits) and found no reports of infection in participants observed during the study period, but did not compare the AAI participants to a control group (Snipelisky et al., 2016). However, another electronic medical record review study identified eight newly-acquired infections two weeks post AAI therapy in nineteen pediatric oncology patients, but could not definitively attribute these infections to the therapy animal visit as there was no control group of hospitalized pediatric oncology patients not receiving AAl therapy (Chubak et al., 2017).

The ten investigative epidemiological studies described cases of either animals or human patients becoming contaminated as a result of an AAI visit. The strongest weight of evidence was from prospective cohort studies in therapy animals (three studies, see Table 1). Among these studies, the largest sample size was 200 therapy dogs, with most studies ranging from 10 to 20. In addition, the same group of investigators conducted most of these studies and utilized the same cohort of therapy dogs (Lefebvre et al., 2006a, 2008b, 2009, 2006c; Lefebvre \& Weese, 2009). These studies focused on zoonotic pathogen carriage in therapy animals, and detailed cross-sectional prevalence and longitudinal incidence. They observed asymptomatic carriage of both hospital-associated and novel pathogens, such as methicillin-resistant 
Staphylococcus aureus (MRSA), Clostridium/Clostridioides difficile, Salmonella, Pasteurella, and intestinal helminths. This investigator group sampled therapy animals longitudinally over 12 months, and detected incidence rate ratios for therapy dogs with hospital exposure compared to no hospital exposure of 4.7 for MRSA acquisition and 2.4 for $C$. difficile acquisition (Lefebvre et al., 2009). They also identified risk factors for acquiring or being colonized with these pathogens, such as a raw meat diet, being fed treats by patients, and licking patients. One of these studies uniquely sampled therapy animals' human handlers for hospital-associated pathogen contamination before and after an AAI visit and demonstrated no contamination related to the AAI visit on the handlers' hands $(\mathrm{N}=26)$ (Lefebvre \& Weese, 2009). The five other epidemiological studies, not from that investigator group and study population, surveilled therapy animals and found a positive association between therapy visits and zoonotic pathogens. Two were case reports of zoonotic pathogens found in therapy animals (Enoch et al., 2005; Sillery et al., 2004). The three cohort studies found prevalence rates of zoonotic pathogen carriage in therapy animals of $11.8 \%$ (Boyle et al., 2019), 18.2\% (Coughlan et al., 2010), and 24.3\% (Gerardi et al., 2018).

Unfortunately, all of these studies ignored assessment of the human patient, as well as assessment of other individuals involved in AAI, such as healthcare workers, visitors, and, with the exception of the one study mentioned above, the therapy animal handlers. No studies evaluated the hospital environment as a source of pathogens, and the literature included scant data on the clinical health outcomes of the animals themselves. Furthermore, no studies systematically measured risk other than zoonotic pathogens/infectious diseases, such as phobias, allergies, or injuries. 
medRxiv preprint doi: https://doi.org/10.1101/2020.02.19.20025130; this version posted February 23, 2020. The copyright holder for this preprint (which was not certified by peer review) is the author/funder, who has granted medRxiv a license to display the preprint in perpetuity.

All rights reserved. No reuse allowed without permission.

\section{Discussion}

While most of the literature currently available on animal-assisted interventions centers mainly on positive human psychosocial outcomes, there is an apparent lack of information and guiding data surrounding the potential infection control challenges to the inclusion of therapy animals in a healthcare setting. As evidenced by the relatively few and mostly small epidemiological studies discussed in this review $(n=10)$, therapy animals can harbor hospital-associated pathogens, and while not validated in controlled research, these data are consistent with the hypothesis that animal contact with patient populations may increase the animal's risk for contamination with pathogens. This is best evident in the study that showed therapy dogs that visit hospitals have almost five times higher odds of carrying MRSA as therapy dogs who visit other locations, such as schools (Lefebvre et al., 2009). Additional research is needed to investigate whether therapy animals can serve as pathogen vectors, from being contaminated by contact with one patient, and then transmitting these pathogens to another patient, leading to pathogen exchange. This is critical to test since many patients served by these therapy animals have a compromised health status and may be at higher risk of infection compared to the general population.

While there are proposed guidelines published for AAI in hospitals, senior care facilities, and for individual animal therapy organizations, there are significant differences in infection control policies across these groups (Serpell et al., 2020). This can cause confusion among therapy animal handlers and individuals who participate in AAI programs and may be complicated by a lack of standardized, evidence-based standard-of-care protocols that can be universally adopted. Current guidelines, including the SHEA guidelines, are based on biological plausibility and originate from hospital fomite research and zoonotic transmission in other situations (pets in the home, etc.). Yet it is likely that therapy animals, with their unique exposures and ability to serve as an interactive living fomite, may have microbial communities that are different from 
medRxiv preprint doi: https://doi.org/10.1101/2020.02.19.20025130; this version posted February 23, 2020. The copyright holder for this preprint (which was not certified by peer review) is the author/funder, who has granted medRxiv a license to display the preprint in perpetuity.

All rights reserved. No reuse allowed without permission.

standard pet animals. Therefore, exposure to animals in an AAl setting may fundamentally differ from exposure to household pets. This unique exposure profile could logically result in different risk factors and protective factors for pathogen contamination for both participants and the therapy animals. As such, infection control guidelines that rely on previous research on fomites and pet ownership may not realistically reflect adequate control measures for therapy animal exposures.

Our review confirmed an even greater lack of quantitative research on hazards other than infectious disease agents in the context of AAI studies. While some articles commented on the risks of phobias, injuries, negative cultural perception of animals, and allergies, none examined these risk factors empirically. Explanations for few study findings in this area include that these highly-trained animals minimize the potential risk of injury and that patients, along with their supervising medical team, will self-select to participate in these programs, thus reducing therapy animal contact by those patients who have phobias or allergies.

Our review also suggested a lack of effective educational campaigns and open communication networks between hospital infection control departments and therapy animal handlers regarding infection risk. This was suggested both by the variability in control practices among institutions and by the knowledge disparities among handlers observed in multiple studies (Boyle et al., 2019; Lefebvre et al., 2006b; Linder et al., 2017). Without these communication channels, therapy animal handlers may not have a clear understanding of the rationale for infection control protocols, as well as the potential risks towards the patients, their therapy animals, and even the handlers themselves. Continued efforts from infection control departments and hospital program facilitators to provide knowledge-based motivation to adhere to hospital-enacted infection control protocols are essential, directed to both therapy animal handlers and healthcare workers involved in AAI sessions. Without such cohesive collaborations, hospital protocols created for AAl programs can be misinterpreted or poorly executed. In order to minimize the potential risk 
medRxiv preprint doi: https://doi.org/10.1101/2020.02.19.20025130; this version posted February 23, 2020. The copyright holder for this preprint (which was not certified by peer review) is the author/funder, who has granted medRxiv a license to display the preprint in perpetuity.

All rights reserved. No reuse allowed without permission.

for all involved, attention should be paid to outreach and education programs that promote safe practices for both therapy animal handlers and hospital staff. In addition to efforts to harmonize infection control regulations across healthcare facilities, individuals involved in AAI should work within the hospital to integrate AAI programs into the overall institutional safety culture in order to maximize the benefits of these programs.

A strong point of the established research is the evaluation of risk factors for pathogen carriage by therapy animals, namely animals fed a raw-food diet and those that have increased interaction with patients (through licking and being fed treats) are more likely to carry zoonotic pathogens. Studies that focus on risk factors can inform interventions to minimize pathogen carriage by therapy animals, and potentially decrease transmission to the patients with whom they subsequently interact. Expanding this work to studies that examine patient-level risk factors (such as concurrent disease conditions or specific animal-contact behaviors) or AAI-level risk factors (such as the number of patients interacting with the animal) will additionally inform the safety practices of these programs and have significant clinical impact. Clear hospital communication channels that impart infection control guidelines, backed by robust evidencebased science on potential risk factors, can empower healthcare workers and handlers to identify and minimize behaviors that pose risk to patients, therapy animals, and themselves.

The most significant knowledge gap is the lack of epidemiological data demonstrating or testing the transmission of zoonotic and hospital-associated pathogens related to AAI therapy sessions. The few published studies have small sample sizes (only two studies included more than 100 animals) and limited longitudinal data (only four retrospective or prospective cohort studies, two from the same cohort). This clearly limits statistical power to demonstrate even associations between pathogen carriage and AAI visits, much less actual illnesses associated with such carriage. Other than those three cohorts, most studies were cross-sectional or case reports, which limits causal inference because of their inherent inability to establish temporality, control 
medRxiv preprint doi: https://doi.org/10.1101/2020.02.19.20025130; this version posted February 23, 2020. The copyright holder for this preprint (which was not certified by peer review) is the author/funder, who has granted medRxiv a license to display the preprint in perpetuity.

All rights reserved. No reuse allowed without permission.

for confounding, or account for interpersonal variability. The data from these cross-sectional studies and case reports, therefore, have minimal weight in our understanding of how AAI exposure may relate to pathogen carriage in therapy animals, patients, healthcare workers, and the hospital environment.

At present, the studies that have assessed microbial sharing during a therapy session focused only on the microbial carriage of the therapy animal. Testing only the therapy animal demonstrates carriage of a zoonotic pathogen at a single time point, and does not capture a transmission event. Data and evidence for transmission between patients, animals, and the environment are limited without sampling of all these components. Identification of a transmission event requires longitudinal multi-source sampling (humans, animals, and the environment) with molecular typing to identify and distinguish specific microorganisms. Such data are required to trace the source, pathway, and directionality among therapy animals, the hospital environment, and all individuals involved, including patients, visitors, healthcare workers, and therapy animal handlers.

Longitudinal sampling will also allow insight into whether microbial exposure and transient contamination from AAI conditions can progress into stable bacterial replication and colonization, and then progress to a possible infection in both individuals and therapy animals. In the context of hospital-associated pathogens, it is established that exposure is necessary, but not always sufficient, to progress to infection (Weber \& Rutala, 2013); longitudinal sampling can capture these stages of progression, and identify risk factors that promote such progression. This is particularly relevant to clinical outcomes in AAI patient participants, many of whom are children or have compromised health status, making pathogen exposure more likely to progress to an infection. Longitudinal sampling of the therapy animal will also test whether these animals can serve as a vector of disease within and between different hospitals, and in the greater community outside of the hospital, as well as evaluate health outcomes in the animals 
medRxiv preprint doi: https://doi.org/10.1101/2020.02.19.20025130; this version posted February 23, 2020. The copyright holder for this preprint (which was not certified by peer review) is the author/funder, who has granted medRxiv a license to display the preprint in perpetuity. All rights reserved. No reuse allowed without permission.

themselves. With only a few published studies conducted in a small number of single hospitals, and often including the same cohort, the present data are clearly of limited generalizability to other populations. 
medRxiv preprint doi: https://doi.org/10.1101/2020.02.19.20025130; this version posted February 23, 2020. The copyright holder for this preprint (which was not certified by peer review) is the author/funder, who has granted medRxiv a license to display the preprint in perpetuity.

All rights reserved. No reuse allowed without permission.

\section{Conclusions}

Future work in this area should aim to investigate the potential hazards that can occur during a therapy visit, both in terms of potential injury and infection control, and seek to quantify these possible associated hazards, while confirming these hazards do not interfere with the known benefits of AAI. It is recommended that future studies employ a One Health framework, a systems-thinking approach that addresses concerns at the nexus of human health, animal health, and the health of their shared environment, paying particular attention to the relationship between the entities rather than looking at them in isolation (Destoumieux-Garzon et al., 2018). This framework may facilitate future investigations and provide a more holistic view of the microbial dynamics between therapy animals, hospital patients, and the hospital environment.

While further research into risk identification is necessary, clinicians and other healthcare workers who implement or are debating implementing an AAl program must also consider their hospital and patient needs, given the clear and established benefits of these adjunctive programs. A rational decision process involves a cost/benefit risk assessment that provides insight into the likely consequences of a proposed action. Balanced with this is the concept of the precautionary principle, which states that without a risk assessment involving hazard identification and analysis, one should minimize exposure to the potential risk. In the case of AAl programs, while there is an ongoing need for corroborating research, the recommended guidelines for animals in the healthcare setting can provide a starting point and scaffold for infection control policies that, when properly applied and followed, have potential to minimize the known and unknown risk factors, while still maintaining the known benefits as an adjunctive patient therapy, with the ultimate goal of making AAI more accessible and sustainable for patients. Promotion of judiciously-executed AAI programs will increase attention to its usage as a complementary therapy, and prompt awareness of the need for further insight into its safety and value as a critical tool for patient benefit. 


\section{Conflicts of Interests:}

None of the authors declare any conflict of interest.

\section{Disclosure statement}

None of the authors of this manuscript has a financial interest or benefit arising from the direct applications of this research. No specific funding was received for this project.

\section{Author Contributions:}

Conceptualization - all authors

Methodology - KRD

Data curation - KRD + KBW

Formal analysis - KRD

Supervision - MFD

Writing (original draft) - KRD

Writing (review \& editing) - all authors

\section{Funding Source:}

Indirect funding for this research was supported by the National Institutes of Health, Eunice

Kennedy Shriver National Institute of Child Health and Human Development [5R01HD097692-

02]. Funding for KRD is provided by a grant from the U.S. Centers for Disease Control and

Prevention, National Institute for Occupational Safety and Health to the Johns Hopkins

Education and Research Center for Occupational Safety and Health [T42 OH0008428].

\section{Acknowledgements:}

The authors would like to thank Lori Rosman for her assistance with data collection, as well conceptualization of the project along with Dr. Ellen K. Silbergeld. We would also like to thank Dr. Sharmaine Miller for her consultation. 
Figure 1. PRISMA* Flow Diagram for Search Strategy
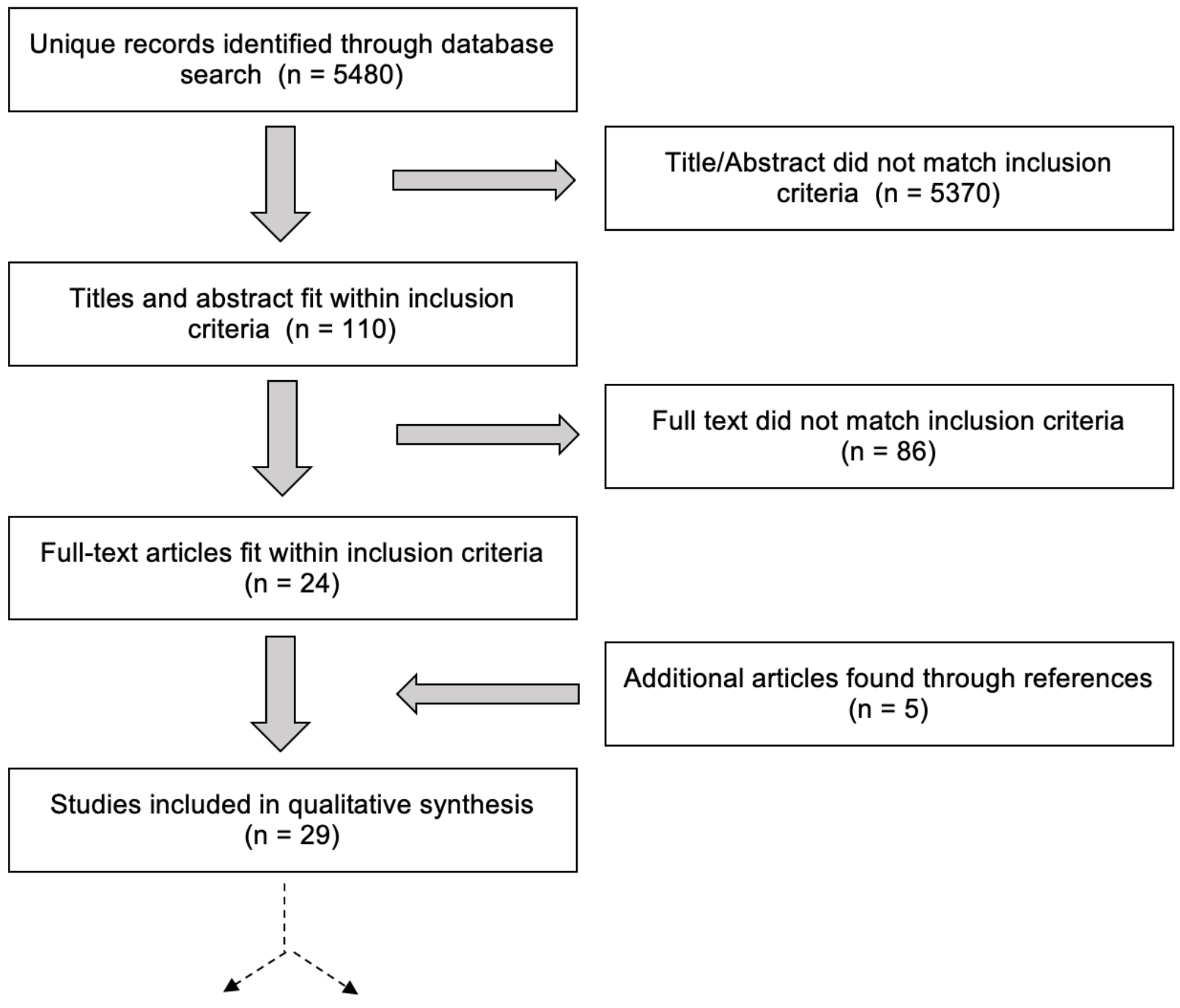

\begin{tabular}{|c|c|}
\hline $\begin{array}{c}\text { Investigative } \\
\text { epidemiological } \\
\text { studies } \\
(n=16)\end{array}$ & $\begin{array}{c}\text { Reviews } \\
\text { and } \\
\text { Commentaries } \\
(n=13)\end{array}$ \\
\hline
\end{tabular}

* Preferred recording of items for systemic reviews and meta-analyses (Moher et al., 2009) 
Table 1. Overview of the Articles Examined: Epidemiological Studies, listed by type and chronologically

\begin{tabular}{|c|c|c|c|c|c|c|}
\hline $\begin{array}{l}\text { Authors, } \\
\text { Year }\end{array}$ & Study Design & Goals & Evaluated & Measurements & Covariates & Findings \\
\hline $\begin{array}{l}\text { (Boyle et al., } \\
2019\end{array}$ & $\begin{array}{l}\text { Epidemiological } \\
\text { Retrospective } \\
\text { Cohort Study } \\
\text { and Survey } \\
\text { Review }\end{array}$ & $\begin{array}{l}\text { Prevalence of zoonotic } \\
\text { pathogens in therapy } \\
\text { animals, and survey of } \\
\text { handlers' understanding } \\
\text { of the risks of zoonoses } \\
\text { and their adherence to } \\
\text { infection control practices }\end{array}$ & $\begin{array}{l}\text { Screening test results } \\
\text { from } 22 \text { dogs and } 2 \text { cats, } \\
\text { with a survey of } 40 \\
\text { registered therapy } \\
\text { animal handlers. }\end{array}$ & $\begin{array}{l}\text { Annual fecal parasitic } \\
\text { float and bacterial } \\
\text { culture, nasal \& perianal } \\
\text { MRSA/MRSP skin } \\
\text { cultures; One-time } \\
\text { structured quantitative } \\
\text { surveys of handlers }\end{array}$ & $\mathrm{N} / \mathrm{A}$ & $\begin{array}{l}17 \text { total positive results of the } 118 \\
\text { infectious disease screenings } \\
\text { performed, } 14 \text { of which were } \\
\text { potentially zoonotic organisms. } \\
70 \% \text { of handlers expressed no } \\
\text { concerns regarding infectious } \\
\text { disease transmission in AAI } \\
\text { settings. }\end{array}$ \\
\hline $\begin{array}{l}\text { (Gerardi et al., } \\
\text { 2018) }\end{array}$ & $\begin{array}{l}\text { Epidemiological } \\
\text { Cross-sectional } \\
\text { Study }\end{array}$ & $\begin{array}{l}\text { Study looked for } \\
\text { protozoan Giardia } \\
\text { duodenalis and zoonotic } \\
\text { gastrointestinal } \\
\text { nematodes over the } \\
\text { three-month study period } \\
\text { in dogs training for AAl. }\end{array}$ & $\begin{array}{l}\text { Fecal samples from } 74 \\
\text { dogs, and demographic } \\
\text { questionnaire data }\end{array}$ & Fecal parasitic exams & $\begin{array}{l}\text { Dog age, } \\
\text { breed, sex, } \\
\text { health status, }\end{array}$ & $\begin{array}{l}\text { Authors found } 18 / 74(24.3 \%) \\
\text { positive fecal samples }-8 \text { with } \\
\text { Giardia, } 3 \text { with co-infections of } \\
\text { multiple gastrointestinal } \\
\text { parasites. }\end{array}$ \\
\hline $\begin{array}{l}\text { (Linder et al., } \\
\text { 2017) }\end{array}$ & $\begin{array}{l}\text { Epidemiological } \\
\text { Cross-Sectional } \\
\text { Survey }\end{array}$ & $\begin{array}{l}\text { Surveyed healthcare } \\
\text { facilities, as well as AAI } \\
\text { organizations, about } \\
\text { animal visitation } \\
\text { guidelines. }\end{array}$ & $\begin{array}{l}45 \text { eldercare facilities, } \\
45 \text { hospitals, and } 27 \\
\text { therapy animal } \\
\text { organizations }\end{array}$ & $\begin{array}{l}\text { Survey assessed } \\
\text { existing health and } \\
\text { safety policies related to } \\
\text { AAI programs }\end{array}$ & $\mathrm{N} / \mathrm{A}$ & $\begin{array}{l}\text { Health and safety policies varied } \\
\text { widely and potentially } \\
\text { compromised human and animal } \\
\text { safety. Hospitals had stricter } \\
\text { guidelines than elderly care } \\
\text { facilities, which had stricter } \\
\text { guidelines that AAl organizations. }\end{array}$ \\
\hline $\begin{array}{l}\text { (Chubak et } \\
\text { al., 2017) }\end{array}$ & $\begin{array}{l}\text { Epidemiological } \\
\text { Retrospective } \\
\text { Cohort Study } \\
\text { and Survey } \\
\text { Review }\end{array}$ & $\begin{array}{l}\text { Pilot study on the risk of } \\
\text { hospital-acquired } \\
\text { infections following an } \\
\text { AAl session in a pediatric } \\
\text { oncology inpatient clinic }\end{array}$ & $\begin{array}{l}\text { Electronic medical } \\
\text { records from } 19 \\
\text { pediatric patients, as } \\
\text { well as patient, parent, } \\
\text { and healthcare provider } \\
\text { surveys. }\end{array}$ & $\begin{array}{l}\text { Newly acquired infection } \\
\text { cases of the participants } \\
\text { for } 14 \text { days following an } \\
\text { AAI session }\end{array}$ & NA & $\begin{array}{l}\text { Eight of the } 19 \text { patients } \\
\text { developed a hospital-associated } \\
\text { infection following an AAI } \\
\text { session. However, this could not } \\
\text { be attributed to AAI therapy } \\
\text { sessions, as there was no control } \\
\text { group to compare whether the } \\
\text { infections resulted from exposure } \\
\text { to AAI versus exposure to the } \\
\text { hospital. }\end{array}$ \\
\hline $\begin{array}{l}\text { (Snipelisky et } \\
\text { al., 2016) }\end{array}$ & $\begin{array}{l}\text { Epidemiological } \\
\text { Retrospective } \\
\text { Cohort Study }\end{array}$ & $\begin{array}{l}\text { Pilot study to test the } \\
\text { feasibility, receptiveness } \\
\text { and safety of AAI in } \\
\text { hospitalized patients } \\
\text { awaiting heart } \\
\text { transplantation. }\end{array}$ & $\begin{array}{l}11 \text { patients followed for } \\
12 \text { months, receiving } \\
146 \text { therapy sessions. }\end{array}$ & $\begin{array}{l}\text { Medical record review } \\
\text { for documented } \\
\text { infections; also surveys } \\
\text { of patient receptiveness } \\
\text { to AAl therapy. }\end{array}$ & $\mathrm{N} / \mathrm{A}$ & $\begin{array}{l}\text { Authors found that while } \\
\text { maintaining strict institutional } \\
\text { infection control policy, no reports } \\
\text { of infection or issues with } \\
\text { intravenous lines, central lines, or } \\
\text { ventricular assist devices, were } \\
\text { observed during the study period. }\end{array}$ \\
\hline $\begin{array}{l}\text { (Coughlan et } \\
\text { al., 2010) }\end{array}$ & $\begin{array}{l}\text { Epidemiological } \\
\text { Prospective } \\
\text { Cohort Study }\end{array}$ & $\begin{array}{l}\text { Prevalence rates of } \\
\text { MRSA in } 12 \text { resident } \\
\text { animals at hospice }\end{array}$ & $\begin{array}{l}11 \text { cats and } 1 \text { dog, over } \\
\text { course of } 8 \text { weeks }\end{array}$ & 1 nasal swab per week & $\begin{array}{l}\text { Health status } \\
\text { of animal }\end{array}$ & $\begin{array}{l}\text { Author found } 2 \text { of the } 11 \text { cats } \\
\text { were positive for MRSA ( } 5 \text { out of } \\
8 \text { samples for one animal, and } 2 \\
\text { out of } 8 \text { samples for the other), all } \\
\text { USA } 100 \text { healthcare-associated } \\
\text { strains. }\end{array}$ \\
\hline
\end{tabular}




\begin{tabular}{|c|c|c|c|c|c|c|}
\hline $\begin{array}{l}\text { (Lefebvre \& } \\
\text { Weese, 2009) }\end{array}$ & $\begin{array}{l}\text { Letter to the } \\
\text { Editor: Case } \\
\text { Report }\end{array}$ & $\begin{array}{l}\text { To show the potential for } \\
\text { therapy animals to } \\
\text { become colonized, not } \\
\text { just transiently } \\
\text { contaminants, with } \\
\text { nosocomial infections }\end{array}$ & $\begin{array}{l}26 \text { therapy dogs with } 26 \\
\text { human handlers }\end{array}$ & $\begin{array}{l}\text { Paws and haircoat of } \\
\text { each dog, and handler's } \\
\text { hands, before and after } \\
\text { therapy visit }\end{array}$ & & $\begin{array}{l}\text { No positive pre-visit samples, } 1 \\
\text { dog }(4 \%) \text { acquired } C \text {. difficile } \\
\text { after a visit, and one human was } \\
\text { positive for MRSA after petting a } \\
\text { therapy dog, suggesting that } \\
\text { dogs can became contaminated } \\
\text { with pathogens during AAI visits, } \\
\text { and can transmit pathogens to } \\
\text { humans. }\end{array}$ \\
\hline $\begin{array}{l}\text { (Lefebvre et } \\
\text { al., 2009) }\end{array}$ & $\begin{array}{l}\text { Epidemiological } \\
\text { prospective } \\
\text { cohort and } \\
\text { nested case- } \\
\text { control studies }\end{array}$ & $\begin{array}{l}\text { To compare the risk of } \\
\text { acquiring a pathogen } \\
\text { between therapy dogs } \\
\text { that visited hospitals } \\
\text { versus therapy dogs that } \\
\text { visited other venues } \\
\text { (classrooms, etc). }\end{array}$ & $\begin{array}{l}96 \text { therapy dogs that } \\
\text { visited hospitals and } 98 \\
\text { dogs that visited other } \\
\text { AAl events. }\end{array}$ & $\begin{array}{l}\text { Fecal and nasal } \\
\text { samples from the dogs } \\
\text { were collected every } 2 \\
\text { months for a year }\end{array}$ & $\begin{array}{l}\text { Dog diet, dog } \\
\text { illnesses, } \\
\text { and } \\
\text { antimicrobial } \\
\text { use within } \\
\text { the home }\end{array}$ & $\begin{array}{l}\text { Therapy dogs that visited } \\
\text { hospitals were almost } 5 \text { times } \\
\text { more likely to be contaminated } \\
\text { with healthcare associated } \\
\text { pathogens (IRR } 4.7 \text { MRSA, } 2.9 \\
\text { C. difficile). Amongst those, } \\
\text { therapy dogs that licked patients' } \\
\text { hands were more likely to be } \\
\text { contaminated. }\end{array}$ \\
\hline $\begin{array}{l}\text { (Lefebvre et } \\
\text { al., 2008b) }\end{array}$ & $\begin{array}{l}\text { Epidemiological } \\
\text { Prospective } \\
\text { Cohort Study }\end{array}$ & $\begin{array}{l}\text { To determine if pathogen } \\
\text { shedding is different in } \\
\text { therapy dogs fed raw } \\
\text { meat diet versus not }\end{array}$ & 200 therapy dogs & $\begin{array}{l}\text { Fecal samples collected } \\
\text { every } 2 \text { months for } 1 \\
\text { year }\end{array}$ & $\begin{array}{l}\text { Clinical } \\
\text { diarrhea, pig- } \\
\text { ear } \\
\text { consumption }\end{array}$ & $\begin{array}{l}\text { Therapy dogs fed a raw meat diet } \\
\text { were significantly more likely to } \\
\text { shed pathogens, including } \\
\text { antibiotic resistant strains. The } \\
\text { authors recommended these } \\
\text { dogs be excluded from AAI } \\
\text { programs. }\end{array}$ \\
\hline $\begin{array}{l}\text { (Lefebvre et } \\
\text { al., 2006c) }\end{array}$ & $\begin{array}{l}\text { Epidemiological } \\
\text { Cross-Sectional } \\
\text { Study }\end{array}$ & $\begin{array}{l}\text { Evaluate dogs visiting } \\
\text { hospitals for possible } \\
\text { zoonotic disease } \\
\text { pathogens }\end{array}$ & $\begin{array}{l}102 \text { visitation dogs } \\
\text { (includes therapy } \\
\text { animals and pets visiting } \\
\text { owners) }\end{array}$ & $\begin{array}{l}\text { Fecal sample, hair-coat } \\
\text { brushings and one } \\
\text { rectal, aural, nasal, oral } \\
\text { and pharyngeal swab } \\
\text { were collected from } \\
\text { each dog and tested for } \\
18 \text { specific pathogens. }\end{array}$ & $\begin{array}{l}\text { Canine } \\
\text { demographic } \\
\text { details and } \\
\text { medical } \\
\text { history }\end{array}$ & $\begin{array}{l}\text { Zoonotic pathogens were found } \\
\text { in } 80 \text { of the } 102 \text { dogs }(80 \%) \text {, } \\
\text { which indicates that these dogs } \\
\text { can spread pathogens. The } \\
\text { authors concluded that more } \\
\text { information is needed on risk } \\
\text { factors and transmission routes } \\
\text { to better inform infection control } \\
\text { policies }\end{array}$ \\
\hline $\begin{array}{l}\text { (Lefebvre et } \\
\text { al., 2006b) }\end{array}$ & $\begin{array}{l}\text { Epidemiological } \\
\text { Cross- Sectional } \\
\text { Survey }\end{array}$ & $\begin{array}{l}\text { To determine the } \\
\text { distribution of canine- } \\
\text { visitation programs in } \\
\text { Ontario and to } \\
\text { characterize the nature of } \\
\text { the programs the dogs } \\
\text { are affiliated with. }\end{array}$ & $\begin{array}{l}\text { Surveys from } 223 \\
\text { hospitals and } 90 \text { therapy } \\
\text { dog handlers }\end{array}$ & $\begin{array}{l}\text { Surveys from hospitals } \\
\text { regarding their usage of } \\
\text { AAI programs. Surveys } \\
\text { from therapy dog } \\
\text { handlers regarding } \\
\text { where they volunteer. }\end{array}$ & $\begin{array}{l}\text { Hospital type } \\
\text { (acute } \\
\text { versus } \\
\text { chronic } \\
\text { care), dog } \\
\text { demographic } \\
\text { s (age, sex, } \\
\text { breed). }\end{array}$ & $\begin{array}{l}\text { Acute care wards were } 5.1 \text { times } \\
\text { more likely than other wards to } \\
\text { prohibit therapy animals. } \\
\text { Handlers reported highly variable } \\
\text { screening protocols and infection } \\
\text { control practices; } 18 \text { owners } \\
\text { ( } 20 \% \text { ) said they did not practice } \\
\text { any infection control and } 36 \\
\text { owners ( } 40 \%) \text { were unable to } \\
\text { name one zoonotic disease }\end{array}$ \\
\hline
\end{tabular}




\begin{tabular}{|c|c|c|c|c|c|c|}
\hline $\begin{array}{l}\text { (Lefebvre et } \\
\text { al., 2006a) }\end{array}$ & $\begin{array}{l}\text { Letter to the } \\
\text { Editor: Case } \\
\text { Report }\end{array}$ & $\begin{array}{l}\text { Report of a toxin-variant } \\
\text { strain of } C \text {. difficile in an } \\
\text { apparently healthy } \\
\text { therapy dog. }\end{array}$ & $\begin{array}{l}1 \text { dog that was a part of } \\
\text { the cross-sectional study } \\
\text { described above }\end{array}$ & Fecal sample & $\mathrm{N} / \mathrm{A}$ & $\begin{array}{l}\text { This canine isolate is } \\
\text { indistinguishable from the major } \\
\text { strain implicated in outbreaks of } \\
\text { highly virulent CDAD around the } \\
\text { world. The recurrent exposure of } \\
\text { this dog to human healthcare } \\
\text { settings suggests that the animal } \\
\text { acquired this strain during visits } \\
\text { to the hospital. }\end{array}$ \\
\hline $\begin{array}{l}\text { (Caprilli \& } \\
\text { Messeri, } \\
\text { 2006) }\end{array}$ & $\begin{array}{l}\text { Ecological } \\
\text { hospital-based } \\
\text { medical record } \\
\text { review }\end{array}$ & $\begin{array}{l}\text { Determine rates of } \\
\text { hospital-acquired } \\
\text { infections before and after } \\
\text { the implementation of an } \\
\text { AAl program, and patient- } \\
\text { reported enjoyment }\end{array}$ & $\begin{array}{l}138 \text { pediatric patient } \\
\text { participants and } \\
\text { aggregated hospital- } \\
\text { wide infection rates }\end{array}$ & $\begin{array}{l}\text { Cases of newly acquired } \\
\text { infections prior to } \\
\text { introducing therapy } \\
\text { dogs, and one year after } \\
\text { dogs present in hospital }\end{array}$ & NA & $\begin{array}{l}\text { Authors found constant rates of } \\
\text { hospital infections after } 1 \text { year of } \\
\text { dogs being present in the hospital } \\
\text { weekly, compared to the previous } \\
\text { year, and no documented } \\
\text { contagious diseases were } \\
\text { transmitted by dogs during their } \\
\text { presence in the hospital. }\end{array}$ \\
\hline $\begin{array}{l}\text { (Enoch et al., } \\
2005)\end{array}$ & $\begin{array}{l}\text { Letter to the } \\
\text { Editor: Case } \\
\text { Report }\end{array}$ & $\begin{array}{l}\text { Describe a case of a } \\
\text { therapy dog acquiring } \\
\text { MRSA during a therapy } \\
\text { visit to a hospital }\end{array}$ & $1 \mathrm{dog}$ & $\begin{array}{l}\text { Nasal, head and paw } \\
\text { swabs before and after } \\
\text { therapy visit }\end{array}$ & $\mathrm{N} / \mathrm{A}$ & $\begin{array}{l}\text { The dog was negative for MRSA } \\
\text { on entering the hospital, but was } \\
\text { found positive when leaving, } \\
\text { indicating patients may spread } \\
\text { MRSA to therapy dogs. }\end{array}$ \\
\hline $\begin{array}{l}\text { (Sillery et al., } \\
\text { 2004) }\end{array}$ & $\begin{array}{l}\text { Letter to the } \\
\text { Editor: Case } \\
\text { Report }\end{array}$ & $\begin{array}{l}\text { Describe a case of a } \\
\text { patient with Pasteurella } \\
\text { peritonitis that was } \\
\text { suspected to be } \\
\text { transmitted from the pet } \\
\text { cat. }\end{array}$ & $\begin{array}{l}1 \text { human patient with a } \\
\text { pet cat }\end{array}$ & $\mathrm{N} / \mathrm{A}$ & $\mathrm{N} / \mathrm{A}$ & $\begin{array}{l}\text { Therapy animals can potentially } \\
\text { transmit Pasteurella multocida, a } \\
\text { pathogen that can cause } \\
\text { peritonitis in patients undergoing } \\
\text { peritoneal dialysis. This is the first } \\
\text { documented case of suspected } \\
\text { transmission of the pathogen } \\
\text { from animals, and introduces a } \\
\text { novel control point for AAI } \\
\text { programs. }\end{array}$ \\
\hline $\begin{array}{l}\text { (Waltner- } \\
\text { Toews, 1993) }\end{array}$ & $\begin{array}{l}\text { Epidemiological } \\
\text { Cross-Sectional } \\
\text { Survey }\end{array}$ & $\begin{array}{l}\text { First documented attempt } \\
\text { to understand risk } \\
\text { associated with AAI. } \\
\text { Surveyed animal care } \\
\text { facilities to determine the } \\
\text { prevalence of AAI } \\
\text { programs, concerns and } \\
\text { experiences with AAI, and } \\
\text { zoonotic disease } \\
\text { precautions taken to } \\
\text { prevent transmission }\end{array}$ & $\begin{array}{l}150 \text { systematically } \\
\text { selected United States } \\
\text { animal care agencies } \\
\text { and } 74 \text { Canadian } \\
\text { humane societies }\end{array}$ & $\mathrm{N} / \mathrm{A}$ & $\mathrm{N} / \mathrm{A}$ & $\begin{array}{l}\text { Half of the respondents } \\
\text { expressed concern over zoonotic } \\
\text { diseases, but few were based on } \\
\text { actual experience. Less than half } \\
\text { consulted with a human health } \\
\text { professional about infection } \\
\text { control and only } 10 \% \text { had written } \\
\text { guidelines for prevention of } \\
\text { zoonotic disease transmission. }\end{array}$ \\
\hline
\end{tabular}


Table 2. Overview of the Articles Examined: Reviews, Guidelines, and Commentaries, listed by type and chronologically

\begin{tabular}{|c|c|c|c|c|c|c|}
\hline $\begin{array}{l}\text { First Author, } \\
\text { Year }\end{array}$ & Study Design & Goals & Evaluated & Measurements & Covariates & Findings \\
\hline $\begin{array}{l}\text { (Bert et al., } \\
2016)\end{array}$ & $\begin{array}{l}\text { Systematic } \\
\text { Review }\end{array}$ & $\begin{array}{l}\text { Review current literature } \\
\text { of positive clinical } \\
\text { outcomes and negative } \\
\text { risk to patients from } \\
\text { therapy animals }\end{array}$ & $\begin{array}{l}11 \text { papers looking at the } \\
\text { risk of therapy animals, } \\
\text { which include both } \\
\text { epidemiological studies } \\
\text { and protocol guidelines. }\end{array}$ & $\mathrm{N} / \mathrm{A}$ & $\mathrm{N} / \mathrm{A}$ & $\begin{array}{l}\text { Concluded AAl for hospitalized } \\
\text { patients useful and safe for a } \\
\text { wide range of diseases }\end{array}$ \\
\hline $\begin{array}{l}\text { (Chalmers \& } \\
\text { Dell, 2016) }\end{array}$ & Commentary & $\begin{array}{l}\text { Applying One Health } \\
\text { principles to decrease risk } \\
\text { in therapy dog programs } \\
\text { and further research }\end{array}$ & $\begin{array}{l}\text { Did not include number } \\
\text { of papers formally } \\
\text { reviewed }\end{array}$ & $\mathrm{N} / \mathrm{A}$ & $\mathrm{N} / \mathrm{A}$ & $\begin{array}{l}\text { Author gives a framework for } \\
\text { studying therapy programs in the } \\
\text { animal-human-environment } \\
\text { interface. }\end{array}$ \\
\hline $\begin{array}{l}\text { (Hardin et al., } \\
2016)\end{array}$ & Commentary & $\begin{array}{l}\text { Describe implementation } \\
\text { of a pet therapy program } \\
\text { that includes guidelines } \\
\text { for the prevention of } \\
\text { transmitted infections. }\end{array}$ & $\begin{array}{l}\text { Did not include number } \\
\text { of papers formally } \\
\text { reviewed }\end{array}$ & $N / A$ & $\mathrm{~N} / \mathrm{A}$ & $\begin{array}{l}\text { Guidelines were in place in a } \\
\text { hospital for sixteen years with no } \\
\text { documented cases of disease } \\
\text { transmission, supporting that a } \\
\text { pet therapy program can be put } \\
\text { into place safely with proper } \\
\text { regulation }\end{array}$ \\
\hline $\begin{array}{l}\text { (Cimolai, } \\
2015)\end{array}$ & $\begin{array}{l}\text { Letter to the } \\
\text { Editor: Brief } \\
\text { Review }\end{array}$ & $\begin{array}{l}\text { Short review of current } \\
\text { studies/case reports of } \\
\text { zoonotic infections from } \\
\text { pets }\end{array}$ & $\begin{array}{l}\text { Did not include number } \\
\text { of papers formally } \\
\text { reviewed }\end{array}$ & $N / A$ & $\mathrm{~N} / \mathrm{A}$ & $\begin{array}{l}\text { Author concludes that therapy } \\
\text { programs do provide } \\
\text { opportunities for patients to } \\
\text { become exposed to zoonotic } \\
\text { infections and requires strict } \\
\text { infection control policies, not a } \\
\text { relaxation of guidelines. }\end{array}$ \\
\hline $\begin{array}{l}\text { (Murthy et al., } \\
2015) \text {, Society } \\
\text { of Healthcare } \\
\text { Epidemiology } \\
\text { of America } \\
\text { (SHEA) } \\
\text { Writing Group }\end{array}$ & Commentary & $\begin{array}{l}\text { Provide general guidance } \\
\text { to the medical community } \\
\text { regarding management of } \\
\text { animals in healthcare, } \\
\text { specifically in terms of } \\
\text { hazard reduction. }\end{array}$ & $\begin{array}{l}\text { Did not include number } \\
\text { of papers formally } \\
\text { reviewed }\end{array}$ & $\mathrm{N} / \mathrm{A}$ & $\mathrm{N} / \mathrm{A}$ & $\begin{array}{l}\text { Created guidelines for animal- } \\
\text { assisted therapies, service } \\
\text { animals, research animals, and } \\
\text { personal pet visitation. Also } \\
\text { recommends additional research } \\
\text { be performed to better } \\
\text { understand the risks and benefits } \\
\text { of allowing animals in the } \\
\text { healthcare setting for specific } \\
\text { purposes }\end{array}$ \\
\hline $\begin{array}{l}\text { (Snipelisky \& } \\
\text { Burton, 2014) }\end{array}$ & Review & $\begin{array}{l}\text { Review current published } \\
\text { information regarding the } \\
\text { efficacy of AAl in the } \\
\text { inpatient population, and } \\
\text { to review safety concerns } \\
\text { associated with AAI. }\end{array}$ & $\begin{array}{l}\text { Reviewed } 44 \text { articles ( } 26 \\
\text { clinical studies, } 15 \\
\text { review articles, } 1 \text { case } \\
\text { report and } 2 \text { letters to } \\
\text { the editor). Five studies } \\
\text { addressed infection } \\
\text { concerns. }\end{array}$ & $N / A$ & $\mathrm{~N} / \mathrm{A}$ & $\begin{array}{l}\text { The authors' review of the } \\
\text { literature showed that, in the } \\
\text { inpatient setting, AAl is an } \\
\text { effective therapy among patients } \\
\text { of all ages and with various } \\
\text { medical problems and is safe, } \\
\text { with no transmitted infections } \\
\text { reported. Found only } 5 \text { studies } \\
\text { that addressed infection concerns } \\
\text { in the inpatient setting. }\end{array}$ \\
\hline
\end{tabular}




\begin{tabular}{|c|c|c|c|c|c|c|}
\hline $\begin{array}{l}\text { (Silveira et al., } \\
\text { 2011) }\end{array}$ & Commentary & $\begin{array}{l}\text { Guidelines for a hospital- } \\
\text { based AAl program, } \\
\text { which has been effective } \\
\text { for a hospital in San } \\
\text { Paolo, Italy }\end{array}$ & $\begin{array}{l}\text { Did not include number } \\
\text { of papers formally } \\
\text { reviewed }\end{array}$ & $\mathrm{N} / \mathrm{A}$ & $\mathrm{N} / \mathrm{A}$ & $\begin{array}{l}\text { AAl programs can be properly } \\
\text { implemented in hospitals if strict } \\
\text { attention is paid to animal } \\
\text { inclusion criteria and infection } \\
\text { control. }\end{array}$ \\
\hline $\begin{array}{l}\text { (Lefebvre et } \\
\text { al., 2008a) }\end{array}$ & Commentary & $\begin{array}{l}\text { Provides standard } \\
\text { guidelines for animal- } \\
\text { assisted interventions in } \\
\text { health care facilities, } \\
\text { considering the available } \\
\text { evidence. }\end{array}$ & $\begin{array}{l}\text { Did not include number } \\
\text { of papers formally } \\
\text { reviewed }\end{array}$ & $\mathrm{N} / \mathrm{A}$ & $\mathrm{N} / \mathrm{A}$ & $\begin{array}{l}\text { Created strict guidelines, } \\
\text { centered on evidenced-based } \\
\text { literature, for AAl programs to } \\
\text { reduce risk of colonization and } \\
\text { transmission of hospital- } \\
\text { associated infections for the } \\
\text { animals and people. }\end{array}$ \\
\hline $\begin{array}{l}\text { (Disalvo et al., } \\
2006 \text { ) }\end{array}$ & Commentary & $\begin{array}{l}\text { Compared guidelines for } \\
\text { therapy animals in } \\
\text { hospitals to guidelines for } \\
\text { service dogs and family } \\
\text { pet visitation }\end{array}$ & $\begin{array}{l}\text { Did not include number } \\
\text { of papers formally } \\
\text { reviewed }\end{array}$ & $\mathrm{N} / \mathrm{A}$ & $\mathrm{N} / \mathrm{A}$ & $\begin{array}{l}\text { Argued that therapy animals } \\
\text { should have strict guidelines to } \\
\text { reduce adverse events such as } \\
\text { phobias, allergies, and zoonotic } \\
\text { diseases. }\end{array}$ \\
\hline $\begin{array}{l}\text { (Sehulster \& } \\
\text { Chinn, 2003) }\end{array}$ & Review & $\begin{array}{l}\text { Centralized CDC } \\
\text { guidelines for } \\
\text { environmental infection- } \\
\text { control strategies and } \\
\text { engineering controls to } \\
\text { effectively prevent } \\
\text { nosocomial infections in } \\
\text { healthcare fields. }\end{array}$ & $\begin{array}{l}\text { Did not include number } \\
\text { of papers formally } \\
\text { reviewed }\end{array}$ & $\mathrm{N} / \mathrm{A}$ & $\mathrm{N} / \mathrm{A}$ & $\begin{array}{l}\text { Discussed general infection } \\
\text { control policies, but also included } \\
\text { therapy animal programs. } \\
\text { Recommended minimizing } \\
\text { contact with animal bodily fluids, } \\
\text { and implementing hand hygiene } \\
\text { after each contact. } \\
\text { Recommended careful selection } \\
\text { of therapy animals and bathing to } \\
\text { reduce allergens. }\end{array}$ \\
\hline $\begin{array}{l}\text { (Brodie et al., } \\
\text { 2002) }\end{array}$ & Review & $\begin{array}{l}\text { Review of current } \\
\text { literature focusing on } \\
\text { health risk to patients }\end{array}$ & $\begin{array}{l}\text { Did not include number } \\
\text { of papers formally } \\
\text { reviewed }\end{array}$ & $\mathrm{N} / \mathrm{A}$ & $\mathrm{N} / \mathrm{A}$ & $\begin{array}{l}\text { Zoonoses, allergies and bites - } \\
\text { the three issues surrounding pet } \\
\text { therapy causing greatest concern } \\
\text { - have the potential to be } \\
\text { controlled in a supervised health } \\
\text { care setting, and can be } \\
\text { minimized by taking simple } \\
\text { measures. }\end{array}$ \\
\hline (Guay, 2001) & Review & $\begin{array}{l}\text { Review of the most } \\
\text { common zoonotic } \\
\text { infections that might be } \\
\text { expected in the long-term } \\
\text { care setting from AAl, } \\
\text { with recommendations for } \\
\text { prevention and control. }\end{array}$ & $\begin{array}{l}\text { Did not include number } \\
\text { of papers formally } \\
\text { reviewed }\end{array}$ & $\mathrm{N} / \mathrm{A}$ & $\mathrm{N} / \mathrm{A}$ & $\begin{array}{l}\text { Recommends infection control } \\
\text { policies and procedures, geared } \\
\text { toward management and } \\
\text { prevention of the different } \\
\text { zoonotic illnesses discussed, } \\
\text { should be developed and } \\
\text { implemented in all nursing homes } \\
\text { offering pet-assisted therapy. }\end{array}$ \\
\hline $\begin{array}{l}\text { (Khan \& } \\
\text { Farrag, 2000) }\end{array}$ & Commentary & $\begin{array}{l}\text { Critique of current animal } \\
\text { therapy programs } \\
\text { guidelines in the context } \\
\text { of hazard reduction }\end{array}$ & $\begin{array}{l}\text { Did not include number } \\
\text { of papers formally } \\
\text { reviewed }\end{array}$ & $\mathrm{N} / \mathrm{A}$ & $\mathrm{N} / \mathrm{A}$ & $\begin{array}{l}\text { If put into place properly, animal } \\
\text { therapy programs can have } \\
\text { significant benefit to patients, with } \\
\text { minimal risk of animal associated } \\
\text { health hazards. }\end{array}$ \\
\hline
\end{tabular}




\section{$\underline{\text { References }}$}

Bert, F., Gualano, M. R., Camussi, E., Pieve, G., Voglino, G., \& Siliquini, R. (2016). Animal assisted intervention $\square$ : A systematic review of benefits and risks. European Journal of Integrative Medicine, 8(5), 695-706. https://doi.org/10.1016/j.eujim.2016.05.005

Boyle, S. F., Corrigan, V. K., Buechner-Maxwell, V., \& Pierce, B. J. (2019). Evaluation of Risk of Zoonotic Pathogen Transmission in a University-Based Animal Assisted Intervention (AAI) Program. Front Vet Sci, 6(167). https://doi.org/10.3389/fvets.2019.00167

Brodie, S., Biley, F., \& Shewring, M. (2002). An exploration of the potential risks associated with using pet therapy in healthcare settings. J Clin Nurs, 11(4), 444-456.

Caprilli, S., \& Messeri, A. (2006). Animal-Assisted Activity at A. Meyer Children's Hospital: A Pilot Study. ECAM, 3(3), 379-383. https://doi.org/10.1093/ecam/nel029

Chalmers, D., \& Dell, C. A. (2016). Applying One Health to the Study of Animal-Assisted Interventions. EcoHealth, 12(4), 560-562. https://doi.org/10.1007/s10393-015-10423.Applying

Chubak, J., Hawkes, R., Dudzik, C., Foose-Foster, J. M., Eaton, L., Johnson, R. H., \& Macpherson, C. F. (2017). Pilot Study of Therapy Dog Visits for Inpatient Youth With Cancer. J Ped Onc Nursing, 34(5), 331-341. https://doi.org/10.1177/1043454217712983

Cimolai, N. (2015). Animal visitation in acute care medical facilities - letter to editor. CMAJ, 187(16), 2015. https://doi.org/10.1503/cmaj.1150069

Coughlan, K., Olsen, K. E., Boxrud, D., \& Bender, J. B. (2010). Methicillin-resistant Staphylococcus aureus in Resident Animals of a Long-term Care Facility. Zoonoses and Public Health, 57(3), 220-226. https://doi.org/10.1111/j.1863-2378.2009.01302.x

Destoumieux-Garzon, D., Mavingui, P., Boetsch, G., Boissier, J., Darriet, F., Duboz, P., ... Voituron, Y. (2018). The One Health Concept: 10 Years Old and a Long Road Ahead. Frontiers in Veterinary Science, 5, 14. https://doi.org/10.3389/fvets.2018.00014

Disalvo, H., Haiduven, D., Johnson, N., Reyes, V. V, Hench, C. P., Shaw, R., \& Stevens, D. A. (2006). Who let the dogs out $\square$ ? Infection control did $\square$ : Utility of dogs in health care settings and infection control aspects. Am J Infect Control, 34(5), 301-307. https://doi.org/10.1016/j.ajic.2005.06.005

Enoch, D. A., Karas, J. A., Slater, J. D., Emery, M. M., Kearns, A. M., \& Farrington, M. (2005). MRSA carriage in a pet therapy dog. J Hosp Infect, 60(2), 186-188. https://doi.org/10.1016/j.jhin.2004.09.035

Gerardi, F., Santaniello, A., Prete, L. Del, Maurelli, M. P., Menna, L. F., Rinaldi, L., ... Menna, L. F. (2018). Parasitic infections in dogs involved in animal-assisted interventions. Italian Journal of Animal Science, 17(1), 269-272. https://doi.org/10.1080/1828051X.2017.1344937

Guay, D. R. P. (2001). Pet-assisted therapy in the nursing home setting: Potential for zoonosis. Am J Infect Control, 29(3), 178-186. https://doi.org/10.1067/mic.2001.115873

Haun, N., Hooper-lane, C., \& Safdar, N. (2016). Healthcare Personnel Attire and Devices as Fomites: A Systematic Review. Infection Control and Hospital Epidemiology, 37(11). https://doi.org/10.1017/ice.2016.192

Kamioka, H., Okada, S., Tsutani, K., Park, H., Okuizumi, H., Handa, S., ... Mutoh, Y. (2014). Effectiveness of animal-assisted therapy $\square$ : A systematic review of randomized controlled trials. Complementary Therapies in Medicine, 22(2), 371-390. 
medRxiv preprint doi: https://doi.org/10.1101/2020.02.19.20025130; this version posted February 23, 2020. The copyright holder for this preprint (which was not certified by peer review) is the author/funder, who has granted medRxiv a license to display the preprint in perpetuity. All rights reserved. No reuse allowed without permission.

https://doi.org/10.1016/j.ctim.2013.12.016

Khan, M. A., \& Farrag, N. (2000). Animal - assisted activity and infection control implications in a healthcare setting. J Hosp Infect, 46(1), 4-11. https://doi.org/10.1053/jhin.2000.0785

Lefebvre, S. L., Arroyo, L. G., \& Weese, J. S. (2006a). Epidemic Clostridium difficile Strain in Hospital Visitation Dog Streptobacillus moniliformis Endocarditis. Emerging Infect Dis, 12(6), 6-7.

Lefebvre, S. L., Golab, J. S., Christensen, E., Castrodale, L., Aureden, K., Bialachowski, A., ... Weese, J. S. (2008a). Guidelines for animal-assisted interventions in health care facilities. Am J Infect Control, 36(7), 78-85. https://doi.org/10.1016/j.ajic.2007.09.005

Lefebvre, S. L., Reid-Smith, R., Boerlin, P., \& Weese, J. S. (2008b). Evaluation of the Risks of Shedding Salmonellae and Other Potential Pathogens by Therapy Dogs Fed Raw Diets in Ontario and Alberta. Zoonoses and Public Health, 55(8-10), 470-480.

https://doi.org/10.1111/j.1863-2378.2008.01145.x

Lefebvre, S. L., Reid-Smith, R. J., Waltner-Toews, D., \& Weese, J. S. (2009). Incidence of acquisition of methicillin-resistant Staphylococcus aureus, Clostridium difficile, and other healthcare-associated pathogens by dogs that participate in animal-assisted interventions. JAVMA, 234(11).

Lefebvre, S. L., Waltner-Toews, D., Peregrine, A., Reid-Smith, R., Hodge, L., \& Weese, J. S. (2006b). Characteristics of Programs Involving Canine Visitation of Hospitalized People in Ontario. Infect Control Hosp Epidemiol, 27(7), 754-758.

Lefebvre, S. L., Waltner-Toews, D., Peregrine, A. S., Reid-Smith, R., Hodge, L., Arroyo, L. G., \& Weese, J. S. (2006c). Prevalence of zoonotic agents in dogs visiting hospitalized people in Ontario: implications for infection control. J Hosp Infect, 62(4), 458-466. https://doi.org/10.1016/j.jhin.2005.09.025

Lefebvre, S. L., \& Weese, J. S. (2009). Contamination of pet therapy dogs with MRSA and Clostridium difficile. J Hosp Infect, 72(3), 268-269.

https://doi.org/10.1016/j.jhin.2009.02.019

Linder, D. E., Siebens, H. C., Mueller, M. K., Gibbs, D. M., \& Freeman, L. M. (2017). Animalassisted interventions: A national survey of health and safety policies in hospitals, eldercare facilities, and therapy animal organizations. Am J Infect Control, 45(8), 883-887. https://doi.org/10.1016/j.ajic.2017.04.287

Lundqvist, M., Carlsson, P., Sjödahl, R., Theodorsson, E., \& Levin, L. Å. (2017). Patient benefit of dog-assisted interventions in health care: A systematic review. BMC Complementary and Alternative Medicine, 17(1), 1-12. https://doi.org/10.1186/s12906-017-1844-7

Maujean, A., Pepping, C. A., \& Kendall, E. (2015). A systematic review of randomized controlled trials of animal-assisted therapy on psychosocial outcomes. Anthrozoos, 28(1), 23-36. https://doi.org/10.2752/089279315X14129350721812

Miller, S. A., \& Forrest, J. L. (2001). Enhancing your practice through evidence-based decision making: PICO, learning how to ask good questions. Journal of Evidence-Based Dental Practice, 1(2), 136-141. https://doi.org/10.1067/med.2001.118720

Moher, D., Liberati, A., Tetzlaff, J., \& Altman, D. G. (2009). Preferred reporting items for systematic reviews and meta-analyses: the PRISMA statement. Journal of Clinical Epidemiology, 62(10), 1006-1012. https://doi.org/10.1016/j.jclinepi.2009.06.005

Murthy, R., Bearman, G., Brown, S., Bryant, K., Chinn, R., Hewlett, A., ... Weber, D. J. (2015). Animals in Healthcare Facilities $\square$ : Recommendations to Minimize Potential Risks. Infect 
Control Hosp Epidemiol, 36(5), 495-516. https://doi.org/10.1017/ice.2015.15

Sehulster, L., \& Chinn, R. (2003). Guidelines for environmental infection control in health-care facilities. Recommendations of CDC and the Healthcare Infection Control Practices Advisory Committee (HICPAC). MMWR (Morb Mortal Wkly Rep) CDC, 52(10), 1-42.

Serpell, J. (1996). In the company of animals: A study of human-animal relationships. Cambridge University Press.

Serpell, J. A., Kruger, K. A., Freeman, L. M., Griffin, J. A., \& Ng, Z. Y. (2020). Current Standards and Practices Within the Therapy Dog Industry: Results of a Representative Survey of United States Therapy Dog Organizations. Frontiers in Veterinary Science, 7(February), 112. https://doi.org/10.3389/fvets.2020.00035

Serpell, J., McCune, S., Gee, N., \& Griffin, J. A. (2017). Current challenges to research on animal-assisted interventions. Applied Developmental Science, 21(3), 223-233. https://doi.org/10.1080/10888691.2016.1262775

Sillery, J., Hargreaves, J., Marin, P., Lerma, E., Kuznia, C., \& Abbe, C. (2004). Pasteurella multocida peritonitis $\square$ : another risk of animal - assisted therapy. Infection Control and Hospital Epidemiology, 25(1), 5-6.

Snipelisky, D., Duello, K., Gallup, S., Myrick, J., Taylor, V., Yip, D., ... Burton, M. C. (2016). Feasibility of Canine Therapy Among Hospitalized Pre-Heart Transplant Patients. Southern Med Journal, 109(3), 154-157. https://doi.org/10.14423/SMJ.0000000000000420

Waltner-Toews, D. (1993). Zoonotic disease concerns in animal-assisted therapy and animal visitation programs. The Canadian Veterinary Journal = La Revue Veterinaire Canadienne, 34(9), 549-551.

Weber, D. J., \& Rutala, W. A. (2013). Understanding and Preventing Transmission of Healthcare-Associated Pathogens Due to the Contaminated Hospital Environment. Infection Control \& Hospital Epidemiology, 34(5), 449-452. https://doi.org/10.1086/670223 